\title{
Antioxidative and Hepatoprotective Activities of Deinoxanthin-Rich Extract from Deinococcus radiodurans R1 against Carbon Tetrachloride-Induced Liver Injury in Mice
}

\author{
Jianhui Cheng ${ }^{1,2}$, Zuofa Zhang ${ }^{2}$, Zhiguo Zheng ${ }^{1,3}$, Guoying Lv², Liangyan \\ Wang $^{1}$, Bing Tian ${ }^{1}$ and Yuejin Hua ${ }^{1 *}$ \\ ${ }^{1}$ Institute of Nuclear-Agricultural Sciences, Zhejiang University, Kaixuan Road No. 268, 310029 Hangzhou, ${ }^{2}$ Department of \\ Horticulture, Zhejiang Academy of Agricultural Sciences, Shiqiao Road No. 139, 310021 Hangzhou, ${ }^{3}$ Cancer Research \\ Institute, Zhejiang Cancer Hospital, Guangji Road No. 139, 310020 Hangzhou, China
}

*For correspondence: Email: yjhua@zju.edu.cn; Tel: +86 57186971703

\begin{abstract}
Purpose: To investigate the antioxidant activity and hepatoprotective effect of deinoxanthin-rich extract from Deinococcus radiodurans (EDR) against $\mathrm{CCl}_{4}$-induced liver injury in mice.

Methods: The ethanol extract of EDR was analyzed by liquid chromatography/mass spectrometry (LC/MS), and its antioxidant activity was examined using in vitro assays for reducing power, iron chelating activity and lipid peroxidation. The extract was also evaluated for its hepatoprotective activity against carbon tetrachloride-induced liver injury in mice. The activities of alanine aminotransferase $(A L T)$, aspartate aminotransferase (AST), alkaline phosphatase (ALP) in serum, and catalase (CAT), superoxide dismutase (SOD) and glutathione peroxidase (GSH-Px) in liver tissue, as well as hepatic malondialdehyde (MDA) levels, were measured to monitor liver injury. Damage to liver cells was assessed by histology.

Results: EDR displayed strong reducing activity and lipid peroxidation inhibition activity in vitro. Pretreatment with EDR (400 mg/kg b.w.) significantly reduced activities of serum ALT, AST and ALP, as well as hepatic MDA levels ( $p<0.05)$, but increased the activities of GSH-PX, CAT and SOD. Histopathological assessment showed that liver tissue damage was decreased by the protective effect of EDR.

Conclusion: The results show that EDR can protect mice against $\mathrm{CCl}_{4}$-induced hepatic damage by its antioxidant and free radical scavenging activities.
\end{abstract}

Keywords: Antioxidant, Deinoxanthin, Deinococcus radiodurans, Hepatoprotective, Carbon tetrachloride, Liver damage

Tropical Journal of Pharmaceutical Research is indexed by Science Citation Index (SciSearch), Scopus, International Pharmaceutical Abstract, Chemical Abstracts, Embase, Index Copernicus, EBSCO, African Index Medicus, JournalSeek, Journal Citation Reports/Science Edition, Directory of Open Access Journals (DOAJ), African Journal Online, Bioline International, Open-J-Gate and Pharmacy Abstracts

\section{INTRODUCTION}

Free radicals formed during oxidation processes which occur in food products and biological systems are known to be responsible for oxidative deterioration of food, adverse health effects, and accelerated aging [1]. In nature, antioxidants protect living organisms from oxidative stress, and consumption of foods rich in antioxidants is believed to provide protective effects in the human body. However, synthetic antioxidants have also been reported to have 
adverse toxic and possible carcinogenic effects [2]. Due to issues regarding the safety of synthetic antioxidants, the isolation and characterization of natural antioxidants obtained from edible materials has received increased attention [3].

Dietary carotenoids and carotenoid-rich foods are considered to be beneficial for preventing a variety of major diseases, including eye diseases. Carotenoids are naturally synthesized by a variety of organisms, including bacteria, and are efficient scavengers of reactive oxygen species (ROS) [4]. It has been reported that $\beta$ carotene, astaxanthin, capsanthin and bixin inhibit the proliferation and viability of leukemia K562 cells, induce cell apoptosis, and interfere with cell cycle progression [5]. Additionally, pretreatment with astaxanthin attenuates cyclophosphamide-induced oxidative stress and DNA damage in mice [6]. From an industry perspective, use of carotenoid-rich microbes rather than plants provides the advantages of greater chemical extraction efficiency, lower production costs, and not having to be concerned with factors of weather or origin of the supply source. Deinococcus radiodurans $\mathrm{R} 1$ is a nonphotosynthetic bacterium well known for its resistance to gamma and UV radiation, oxidants, and desiccation. The microbe can survive a $\mathrm{y}$-ray dose of $\sim 12 \mathrm{kGy}$, which can generate about 200 double strand breaks and 3000 single strand breaks per genome [7]. Endogenous antioxidants play an important role in the resistance capabilities of $D$. radiodurans, and it has been shown that the bacterium can synthesize a unique carotenoid (a non-enzymatic antioxidant), deinoxanthin [8]. In our previous study, a deinoxanthin extract derived from $D$. radiodurans (EDR) exhibited significantly stronger ROSscavenging activity than either lycopene or betacarotene. Additionally, because deinoxanthin is a high-efficiency scavenger of hydroxyl radicals and singlet oxygen, the extract also protected DNA from damage and prevented oxidation of proteins $[9,10]$.

Based on the strong antioxidant activities demonstrated in vitro, we decided to evaluate the effects of a deinoxanthin extract on mammalian cells. Carbon tetrachloride $\left(\mathrm{CCl}_{4}\right)$ is a well-known hepatotoxin, and exposure to this chemical is known to induce oxidative stress and cause liver damage due to formation of free radicals [11]. In this study, we report for the first time the effects of deinoxanthin-rich extract derived from $D$. radiodurans on $\mathrm{CCl}_{4}$-induced hepatic damage in mice.

\section{EXPERIMENTAL}

\section{Materials and Chemicals}

D. radiodurans R1 (ATCC 13939) cultures were grown at $30^{\circ} \mathrm{C}$ in tryptone-glucose-yeast extract (TGY) media $(0.5 \%$ bacto-tryptone, $0.3 \%$ bactoyeast extract, and $0.1 \%$ glucose w/v) with aeration or on TGY plates supplemented with $1.5 \% \mathrm{w} / \mathrm{v}$ agar.

Carbon tetrachloride $\left(\mathrm{CCl}_{4}\right)$, 2-thiobarbituric acid (TBA), malonaldehyde-bis-dimethyl acetal (MDA), $\beta$-carotene and silymarin were purchased from Sigma Aldrich (St. Louis, MO, USA). Ferrozine, ascorbic acid and ethylenediamine tetraacetic acid disodium salt (EDTA) were obtained from Bio Basic (Markham, ON, Canada). Olive oil was obtained from Olitalia (Forlì, Italy). All other chemical reagents used were analytical grade and were purchased from Sangon (Shanghai, China).

\section{Preparation of extract and analysis by LC/MS}

The extract containing deinoxanthin was prepared from $D$. radiodurans according the method described previously [9]. Cells were harvested by centrifugation at $5000 \times \mathrm{g}$ for 10 min from $50 \mathrm{~mL}$ samples of cultures of $D$. radiodurans $\mathrm{R} 1$ grown under aerobic conditions with continuous shaking. After washing three times with sterile water, the cell pellet was extracted three times with cold ethanol $(1: 3, \mathrm{w} / \mathrm{v})$ in the dark followed by centrifugation at $8000 \times \mathrm{g}$ for $10 \mathrm{~min}$ to collect supernatant. The combined supernatant was concentrated at $35^{\circ} \mathrm{C}$ under vacuum (0.08 MPa). It was then freeze-dried to powder to yield EDR, which was dissolved in ethanol (for analysis in vitro) or in olive oil (for animal experiment).

Chromatographic analysis was performed on Waters 1525 HPLC system consisting of an autosampler, a binary pump, a column compartment, a diode array detector and Waters BreezeTM software (Waters Technologies, USA). A Waters SB-C18 column (150 mm × 4.6 $\mathrm{mm}, 5 \mu \mathrm{m}$ particle size) was used for separation of carotenoid extracts. Elution was performed with a mixture of acetonitrile, methanol and isopropanol (40:50:10, v/v) at a flow rate of 0.8 $\mathrm{ml} / \mathrm{min}$. UV spectra were scanned from 220 to $600 \mathrm{~nm}$. Thermo Scientific Q Exactive hybrid quadrupole-Orbitrap mass spectrometer system equipped with ESI source. The system was controlled and data were analysed on a computer equipped with Thermo Scientific Xcalibur 2.2 (Thermo Fisher Scientific, USA). Mass Spectrometer instrument was operated at 
the following parameters: capillary voltage of 3.5 $\mathrm{kV}$; a vaporizer temperature of $325^{\circ} \mathrm{C}$; sheath gas pressure of $40 \mathrm{arb}$; aux gas pressure of 10 arb; full scan mode; resolution of 70,000 ; scan range, m/z $200-1500$.

\section{In vitro assessment of antioxidant activity of EDR}

\section{Assay of reducing power}

The reductive potential of all samples was determined by the method described by Oyaizu [12]. Different concentrations of test samples (0 $10.0 \mu \mathrm{g} / \mathrm{mL}$ ) were mixed with phosphate buffer (2.5 mL, 0.2 M, pH 6.6) and potassium ferricyanide $\left[\mathrm{K}_{3} \mathrm{Fe}(\mathrm{CN})_{6}\right](2.5 \mathrm{~mL}, 1 \% \mathrm{w} / \mathrm{v})$. The mixture was incubated at $50^{\circ} \mathrm{C}$ for $20 \mathrm{~min}$. Trichloroacetic acid $(2.5 \mathrm{~mL}, 10 \% \mathrm{w} / \mathrm{v})$ was added to the mixture, which was then subjected to centrifugation $(10 \mathrm{~min}, 1000 \times \mathrm{g}$ ). The upper layer of solution $(2.5 \mathrm{~mL})$ was removed and mixed with distilled water $(2.5 \mathrm{~mL})$ and $\mathrm{FeCl}_{3}(0.5$ $\mathrm{mL}, 0.1 \% \mathrm{w} / \mathrm{v})$, and the absorbance was measured at $700 \mathrm{~nm}$.

\section{Assay of ferrous ion-chelating activity}

The iron-chelating ability of all the samples was determined by chelation of ferrous ions by either the extracts or control samples and estimation by the method as described previously [13]. In this assay, $0.2 \mathrm{~mL}$ of the samples at different concentrations $(0-10.0 \mu \mathrm{g} / \mathrm{mL})$ was added to a solution of $2 \mathrm{mM} \mathrm{FeCl}_{2}(0.05 \mathrm{~mL})$. The reaction was initiated by the addition of $5 \mathrm{mM}$ ferrozine $(0.2 \mathrm{~mL})$ and the mixture was shaken vigorously and left to stand at room temperature for $10 \mathrm{~min}$. After the mixture had reached equilibrium, the absorbance of the solution was measured at 562 $\mathrm{nm}$. The percentage inhibition of ferrozine-Fe $\mathrm{Fe}^{2+}$ complex formation was determined using the following formula:

\section{Chelating activity $(\%)=\left(A_{0}-A_{1}\right) \times 100 / A_{0}$,}

where $A_{0}$ is the absorbance of the control, and $A_{1}$ is the absorbance of the samples. The control contained $\mathrm{FeCl}_{2}$ and ferrozine complex formation molecules. EDTA was used as positive control.

\section{Assay of effect on lipid peroxidation}

The lipid peroxidation assay was carried out by thiobarbituric acid reactive substances (TBARS) assay using mice liver homogenate as the lipidrich media [14]. Briefly, $1 \mathrm{~g}$ liver tissue was homogenised in cold $100 \mathrm{mM}$ Tris- $\mathrm{HCl}$ buffer $(\mathrm{pH} 7.4)$ and was centrifuged at $3000 \times \mathrm{g}$ for 10 min. $0.1 \mathrm{~mL}$ of $1 \% \mathrm{w} / \mathrm{v}$ liver homogenate was mixed with $0.1 \mathrm{~mL}$ sample solution with different EDR concentrations $(0-10.0 \mu \mathrm{g} / \mathrm{mL})$ and $30 \mu \mathrm{L}$ of $10 \mu \mathrm{M}$ freshly prepared $\mathrm{FeSO}_{4}$. The volume was made up to $0.3 \mathrm{~mL}$ by water before incubation at $37^{\circ} \mathrm{C}$ water bath for $1 \mathrm{~h}$. The colour reaction was carried out by adding $0.2 \mathrm{~mL} 8.1 \%$ $\mathrm{w} / \mathrm{v}$ sodium dodecyl sulphate (SDS), $0.5 \mathrm{~mL}$ acetic acid/ $\mathrm{HCl}(\mathrm{pH} 3.4)$ mixture and $0.5 \mathrm{~mL}$ of thiobarbituric acid solution $(0.6 \% \mathrm{w} / \mathrm{v})$. This mixture was vortexed and incubated at $100^{\circ} \mathrm{C}$ for $1 \mathrm{~h}$. The absorbance was measured at $532 \mathrm{~nm}$ and the absorbance was compared with that of a standard curve using malondialdehyde (MDA). Normal control represented without adding oxidant $\mathrm{FeSO}_{4}$ in reaction mixtures.

\section{Evaluation of protective effect of EDR against $\mathrm{CCl}_{4}$-induced hepatotoxicity in mice}

\section{Experimental protocol}

Forty male ICR mice (weighing 20 - 22 g) were procured from Animal Experiment center of Medical College, Zhejiang University, China. The animals were housed in individual stainless steel cages in an air-conditioned room under $12 \mathrm{~h}$ light I dark cycle. A commercial pellet diet and water were provided throughout the experiment. All procedures were conducted in accordance with the PR China legislation under no. 8910MO047 on the use and care of laboratory animals and with the guidelines established by Institute for Experimental Animals of Zhejiang University.

The mice were randomly divided into five groups with 8 animals in each. Group I - untreated control: mice received olive oil orally from first day to tenth day. Group II - $\mathrm{CCl}_{4}$ : mice received olive oil orally from first day to tenth day, then a single intraperitoneal injection of $0.4 \% \mathrm{CCl}_{4}$ (in olive oil) at $0.1 \mathrm{~mL} / 10 \mathrm{~g} \mathrm{b.w}$. to induce hepatic injury after $1 \mathrm{~h}$ of the olive oil oral on tenth day of study. Group III - EDR (200 mg/kg b.w.) + $\mathrm{CCl}_{4}$, and Group IV - EDR (400 mg/kg b.w.) + $\mathrm{CCl}_{4}$ : mice received a daily dose of EDR dissolved in olive oil (200 and $400 \mathrm{mg} / \mathrm{kg}$ b.w., respectively) orally from first day to tenth day of study, then a single intraperitoneal injection of $0.4 \% \mathrm{CCl}_{4}$ at $0.1 \mathrm{~mL} / 10 \mathrm{~g} \mathrm{b.w}$. after $1 \mathrm{~h}$ of EDR oral on tenth day. Group V - silymarin $+\mathrm{CCl}_{4}$ : mice received a daily dose of silymarin suspension $(100 \mathrm{mg} / \mathrm{kg}$ b.w.) orally from first day to tenth day, then a single intraperitoneal injection of $0.4 \% \mathrm{CCl}_{4}$ at $0.1 \mathrm{~mL} / 10 \mathrm{~g}$ b.w. after $1 \mathrm{~h}$ of silymarin oral on tenth day.

Twenty-four hours after the treatment of $\mathrm{CCl}_{4}$, all mice were anaesthetized using light ether and sacrificed by cervical dislocation. Blood samples were collected by the retroorbital blood-collection 
method, deposited in serum separator gel tubes and centrifuged at $3000 \times \mathrm{g}$ at $4^{\circ} \mathrm{C}$ for $10 \mathrm{~min}$ to obtain serum. Liver samples were dissected out and washed immediately with ice cold physiological saline to remove as much blood as possible, and immediately stored at $-70^{\circ} \mathrm{C}$ until analysis. In addition, portions sample of liver were excised and fixed in $10 \%$ neutral buffered formalin for histopathology.

\section{Assay of serum ALT, AST, and ALP}

Liver damage was assessed by determination of activities of serum ALT, AST and ALP using commercially available kits (Nanjing Jiancheng Bioengineering Institute, China) according to the manufacturer's instructions.

\section{Assay of SOD, CAT, GSH-PX, and MDA in liver homogenate}

Liver homogenates were prepared in cold $0.86 \%$ physiological saline using a homogenizer. The unbroken cells and cell debris were removed by centrifugation at $12000 \times \mathrm{g}$ for $10 \mathrm{~min}$ at $4{ }^{\circ} \mathrm{C}$. The supernatant was used immediately for the assays of CAT, SOD, GSH-Px and MDA. The protein concentration was measured according to the Bradford method using bovine serum albumin as the standard. The enzymes activities and MDA level were determined using commercial kits (Nanjing Jiancheng Bioengineering Institute, China) according to manufacturer's instruction.

\section{Estimation of cellular damage by liver histology}

The liver portions were fixed in $10 \%$ neutral formalin solution for $24 \mathrm{~h}$ and then dehydrated in graded alcohol. The fixed tissue was embedded in molten paraffin wax. Sections from paraffin blocks were cut at $5 \mu \mathrm{m}$, mounted on slides, stained with hematoxylin-sosin (H-E) and examined by a Leica DFC280 light microscope and Leica Q Win and Image Analysis System ( Leica Micros Imaging Solutions Ltd., Cambridge, UK). Overall pathological changes, including cell infiltration, and hepatic cell necrosis were diagnosed according to previously described methods $[15,16]$.

\section{Statistical analysis}

All data were expressed as mean \pm standard deviation (SD) and analyzed by one way ANOVA. $p$-values $<0.05$ were regarded as significant. All statistical analyses were carried out using SPSS 17.0 for Windows (SPSS, Chicago, IL).

\section{RESULTS}

\section{EDR analysis}

The ethanol extract of carotenoids from $D$. radiodurans exhibited $>10$ peaks on an analysis by HPLC (Figure 1). The major component in the extract was peak 2 with $56.8 \%$. This peak showed a mass of 583.4 by ESI/MS, matched the formula $\mathrm{C} 4 \mathrm{OH} 54 \mathrm{O} 3$, and was identified as deinoxanthin.

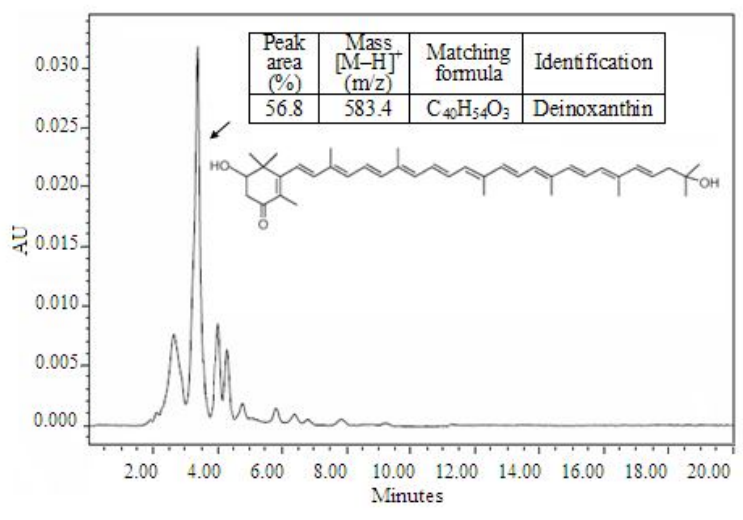

Figure 1: LC/MS analysis of the major component in ethanol extract from $D$. radiodurans $\mathrm{R} 1$

\section{In vitro antioxidant activity of EDR}

\section{Reducing capacity}

As shown in Figure 2A, the reducing abilities of all EDR samples, as well as $\beta$-carotene and ascorbic acid, increased with their increasing concentration; however, the reducing ability of EDR was higher than those of $\beta$-carotene and ascorbic acid. These results confirmed that EDR possesses a higher reducing ability than popularly used antioxidants.

\section{$\mathrm{Fe}^{2+}$ chelating activity}

The $\mathrm{Fe}^{2+}$ chelating effects of all samples were concentration-dependent, and the chelating activity of EDR was weaker than that of EDTA, which was used as a positive control (Figure 2B). At concentrations of $10.0 \mu \mathrm{g} / \mathrm{mL}$, the $\mathrm{Fe}^{2+}$ chelating activities for EDR and EDTA were 9.1 and $29.1 \%$, respectively.

\section{Lipid peroxidation inhibition effect}

The inhibitory effects of EDR on lipid peroxidation increased with increasing sample concentrations (Figure 2C). At a concentration of $10.0 \mu \mathrm{g} / \mathrm{mL}$, EDR inhibited lipid peroxidation by $57.5 \%$, and at a concentration of $10.0 \mu \mathrm{g} / \mathrm{mL}$, the inhibitory effect of extract on lipid peroxidation 
was greater than that of ascorbic acid at 50 $\mu \mathrm{g} / \mathrm{mL}$.
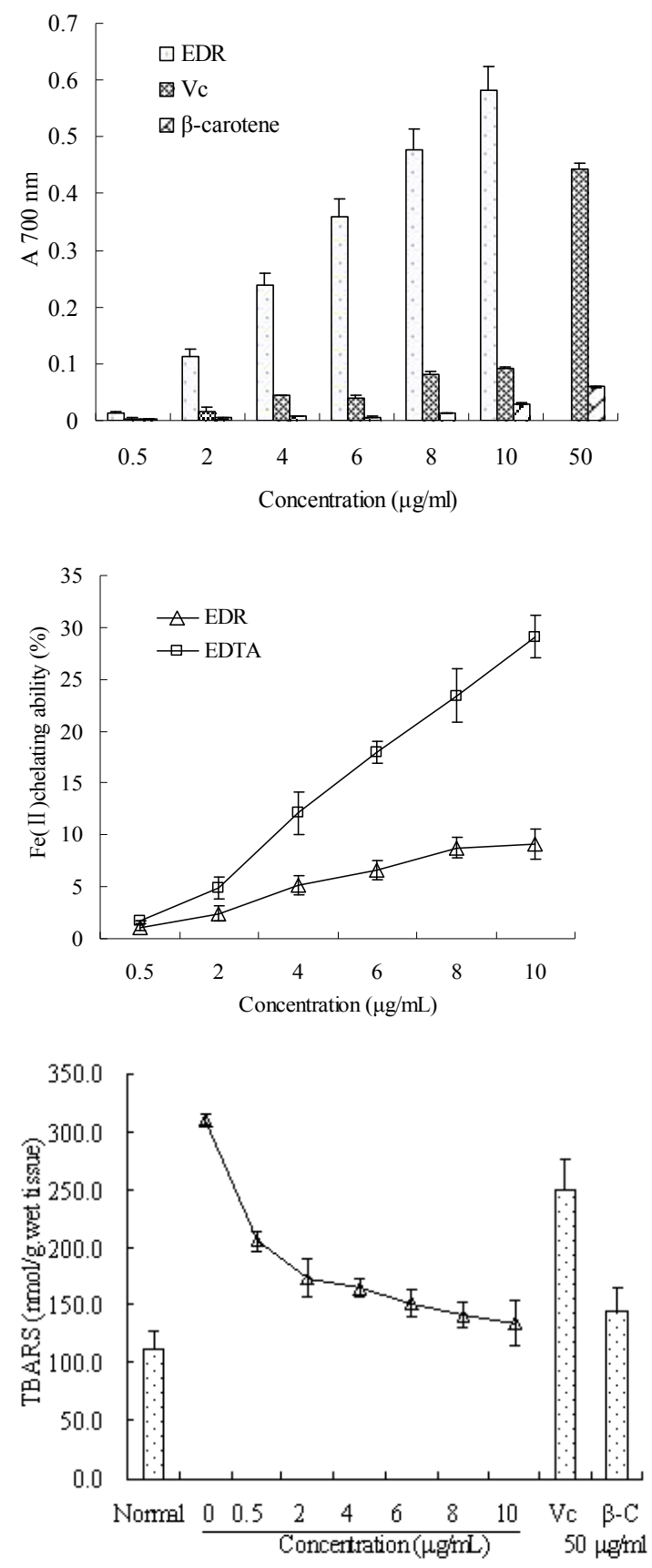

Figure 2: Reducing ability (A), $\mathrm{Fe}^{2+}$ chelating activity $(B)$, and lipid peroxidation inhibition effect (C) of deinoxanthin-rich extract from $D$. radiodurans (EDR). Ascorbic acid (Vc), $\beta$-carotene $(\beta-C)$ and EDTA were used as positive controls. Normal: no $\mathrm{FeSO}_{4}$ oxidant in reaction mixtures. Values are mean $\pm S . D, n=3$

Protective effect of EDR against $\mathrm{CCl} 4$ induced hepatotoxicity in mice

\section{Effect on serum biochemical parameters}

The hepatoprotective effects of EDR on serum biochemical parameters in $\mathrm{CCl}_{4}$-treated mice are shown in Figure 3. Mice treated with $\mathrm{CCl}_{4}$ (Group II) showed significant increases in serum activities of ALT, AST and ALP when compared with control animals (Group I). Pre-treatment of mice with EDR at 200 and $400 \mathrm{mg} / \mathrm{kg} \mathrm{b.w.} \mathrm{for} 10$ days (Groups III and IV) produced significant reductions in serum AST, ALT and ALP activities compared to the model group (Group II).
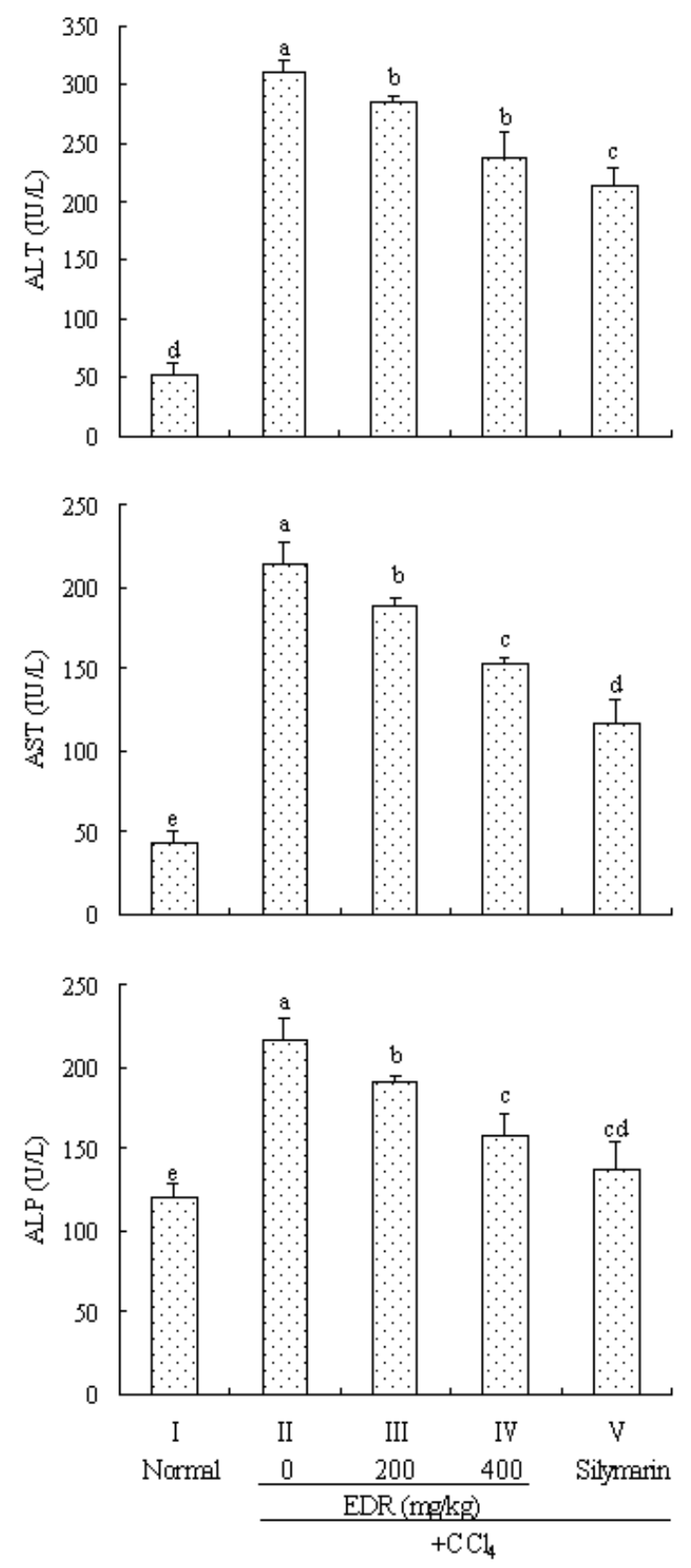

Figure 3: Effect of EDR on activities of serum ALT, AST and ALP in mice with liver damage induced by $\mathrm{CCl}_{4}$. Silymarin at a concentration of $100 \mathrm{mg} / \mathrm{kg}$ was used as positive control. Values are mean \pm S.D, $\mathrm{n}=$ 8. Bars with different letters are significantly $(p<0.05)$ different (Duncan's test) 
Table 1: Effect of pre-treatment with EDR on liver CAT, SOD, GSH-Px and MDA

\begin{tabular}{|c|c|c|c|c|}
\hline Group & $\begin{array}{l}\text { CAT } \\
\text { (U/g protein) }\end{array}$ & $\begin{array}{l}\text { SOD } \\
\text { (U/mg protein) }\end{array}$ & $\begin{array}{l}\text { GSH-Px } \\
\text { (U/mg protein) }\end{array}$ & $\begin{array}{l}\text { MDA } \\
\text { (nmol/mg } \\
\text { protein) }\end{array}$ \\
\hline I (Normal control) & $1762.91 \pm 173.72^{\mathrm{a}}$ & $283.29 \pm 18.97^{a}$ & $960.18 \pm 107.82^{a}$ & $0.38 \pm 0.05^{\mathrm{c}}$ \\
\hline II ( $\mathrm{CCl}_{4}$ control) & $906.53 \pm 99.43^{c}$ & $217.22 \pm 10.46^{c}$ & $546.09 \pm 35.14^{c}$ & $1.21 \pm 0.10^{a}$ \\
\hline $\begin{array}{l}\text { III }\left(200 \mathrm{mg} / \mathrm{kg} \text { EDR }+\mathrm{CCl}_{4}\right) \\
\text { IV }\left(400 \mathrm{mg} / \mathrm{kg} \text { EDR }+\mathrm{CCl}_{4}\right) \\
\text { V }\left(100 \mathrm{mg} / \mathrm{kg} \text { silymarin }+\mathrm{CCl}_{4}\right)\end{array}$ & $\begin{array}{l}1011.78 \pm 16.75^{\mathrm{c}} \\
1118.45 \pm 46.58^{\mathrm{b}} \\
1013.59 \pm 139.13^{\mathrm{bc}}\end{array}$ & $\begin{array}{l}236.21 \pm 30.63^{\mathrm{bc}} \\
247.49 \pm 10.23^{\mathrm{b}} \\
259.38 \pm 16.05^{\mathrm{ab}}\end{array}$ & $\begin{array}{l}682.73 \pm 69.28^{\mathrm{bc}} \\
823.51 \pm 77.64^{\mathrm{ab}} \\
891.43 \pm 55.73^{\mathrm{ab}}\end{array}$ & $\begin{array}{l}1.13 \pm 0.13^{a} \\
0.94 \pm 0.11^{\mathrm{b}} \\
0.84 \pm 0.16^{\mathrm{b}}\end{array}$ \\
\hline
\end{tabular}

\section{Hepatic antioxidant enzyme activities}

Results in Table 1 show that compared to the control group, mice injected with $\mathrm{CCl}_{4}$ showed significant increases in liver malondialdehyde (MDA) levels; however, pretreatment of mice with EDR $(400 \mathrm{mg} / \mathrm{kg}$ b.w.) prevented these increases $(p<0.05)$. Additionally, hepatic activities of CAT, SOD and GSH-Px were significantly decreased in the $\mathrm{CCl}_{4}$-injected mice compared to activities in control mice $(p<0.05)$, and pre-treatment with EDR (400 mg/kg b.w.) increased these activity levels.

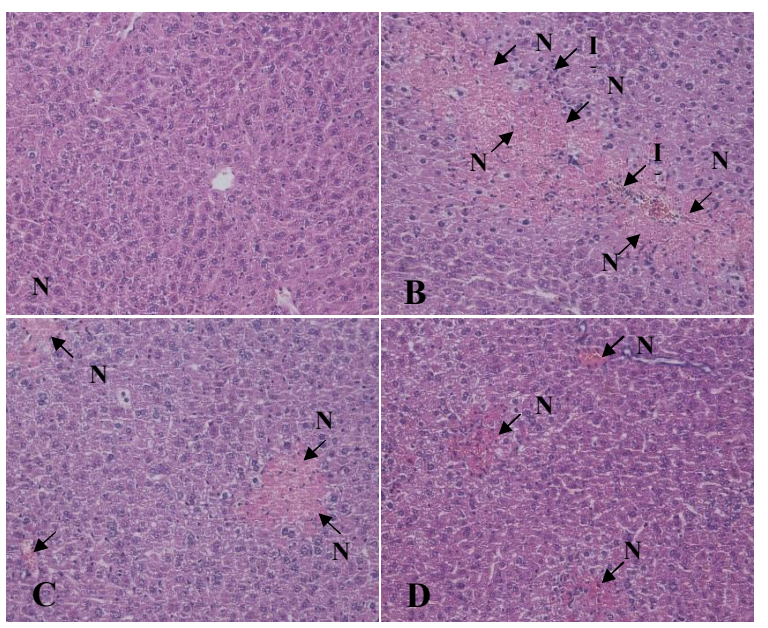

Figure 4: Effect of pre-treatment with EDR on hepatic morphology in mice treated with $\mathrm{CCl}_{4}$. Livers were sectioned and stained with hematoxylin-eosin using standard techniques $(\times 200)$. (A) Normal control, (B) $\mathrm{CCl}_{4}$ control, (C) EDR (400 mg/kg b.w.) $+\mathrm{CCl}_{4}$, and (D) silymarin (100 mg/kg b.w.) + $\mathrm{CCl}_{4}$. A: necrosis; II: inflammatory infiltration

\section{Histopathologic characteristics}

Histopathological examination showed prominent changes, including degeneration, large necrosis and inflammatory cell infiltration in the liver tissue of mice treated with $\mathrm{CCl}_{4}$. However, the degree of tissue damage was significantly less in the groups pretreated with the EDR at a dose of 400 $\mathrm{mg} / \mathrm{kg}$ b.w. (Figure 4).

\section{DISCUSSION}

The carotenoid family of compounds comprises > 600 fat-soluble pigments. These compounds have been widely studied, and special attention has been given to understanding the roles of $\beta$ carotene, lycopene, lutein, zeaxanthin and astaxanthin. Carotenoids are thought to provide health benefits and decrease the risk of various diseases by protecting cells and organisms against the effects of harmful substances [17]. Epidemiologic studies support a protective role of carotenoids in prevention of certain diseases, including certain cancers and eye disease [4], and their primary mechanism of action appears to involve their ability to scavenge reactive oxygen species (ROS). A direct correlation has been reported to exist between the antioxidant and reducing capacities of various molecules [18], and the reducing capacity of a compound or extract may be a significant indicator of its potential antioxidant activity [19]. Lipid peroxidation generates a number of degradation products, including malondialdehyde (MDA), which causes cell membrane destruction and DNA damage [20]. Scavenging of free radicals is one of the major antioxidative mechanisms used by cells to inhibit the chain reactions involved in lipid peroxidation. In this study, a carotenoid-rich extract from $D$. radiodurans demonstrated a strong ferric ion reducing ability and a corresponding ability to inhibit lipid peroxidation in vitro.

$\mathrm{CCl}_{4}$ is widely used to induce hepatotoxicity because it is metabolized in hepatocytes by cytochrome $\mathrm{P} 450$, generating a highly reactive trichloromethyl free radical $\left(\mathrm{CCl}_{3}{ }^{\bullet}\right)$ and a trichloromethyl peroxyl radical $\left(\mathrm{CCl}_{3} \mathrm{O} \cdot\right)$, which initiate a chain of lipid peroxidations which cause cell necrosis, central vein disruption, distended sinusoidal spaces and liver fibrosis [21]. Oxidative stress and lipid peroxidation have been reported to occur during development of $\mathrm{CCl}_{4}$ induced hepatic damage [22]. 
Several antioxidant extracts have been shown to protect the liver against hepatotoxicants [23-26]. Increased activities of AST, ALT and ALP in the serum of $\mathrm{CCl}_{4}$-treated mice compared with those in control mice were indicative of hepatic cell damage and leakage of cytosolic contents into the systemic circulation [27, 28]. In the present study, the elevated activities of all these marker enzymes observed in $\mathrm{CCl}_{4}$-treated mice (Group II) indicated the presence of liver damage induced by toxins. However, pre-treatment with EDR reduced the increases in serum AST, ALT and ALP activities, indicating its hepatoprotective and curative activities.

Liver damage in $\mathrm{CCl}_{4}$-treated mice was also evidenced by the decreased activities of the free radical scavenging enzymes SOD, CAT and GSH-Px. These enzymes constitute a mutually supportive team of defense mechanisms against the harmful effects of ROS biological systems [29]. SOD is an exceedingly effective defense enzyme that reduces the superoxide radical $\left(\mathrm{O}_{2}{ }^{-}\right)$ to form $\mathrm{H}_{2} \mathrm{O}_{2}$ and $\mathrm{O}_{2}$ [30]. CAT is a hemoprotein found in all aerobic cells, and converts $\mathrm{H}_{2} \mathrm{O}_{2}$ to oxygen and water. GSH-Px plays an important role in detoxification of xenobiotics in the liver, and catalyzes reduction of $\mathrm{H}_{2} \mathrm{O}_{2}$ to $\mathrm{H}_{2} \mathrm{O}$ and $\mathrm{O}_{2}$, thereby preventing formation of hydroxyl radicals [31]. The results in the present study show that the activities of SOD, CAT and GSH-Px in mice were decreased by administration of $\mathrm{CCl}_{4}$. However, pretreatment with EDR improved the activities of SOD, CAT and GSH-Px in the livers of $\mathrm{CCl}_{4}$-treated mice. These results suggest that the antioxidative system in liver tended to be normalized by the protective action of EDR. MDA is an indicator of lipid peroxidation, and increased levels of MDA in liver induced by $\mathrm{CCl}_{4}$ suggest enhanced lipid peroxidation, leading to hepatic tissue damage [32]. In the present study, $\mathrm{CCl}_{4}$-induced toxicity caused increases in liver tissue MDA levels as compared to levels in the normal control group, while treatment with EDR caused a significant decrease in MDA levels compared to levels in the $\mathrm{CCl}_{4}$-induced toxicity group. These results suggest that EDR reduced lipid peroxidation and had a significant protective effect against $\mathrm{CCl}_{4}$-induced acute hepatotoxicity in mice. Considering the possible mechanisms for $\mathrm{CCl}_{4}$ toxicity, the observed hepatoprotective effect of EDR could be partially due to its potent antioxidant capacity.

\section{CONCLUSION}

In the current study, EDR demonstrated a strong antioxidant activity in vitro, and this effect was further verified by its ability to suppress hepatic damage resulting from $\mathrm{CCl}_{4}$-induced oxidative stress in mice. Pretreatment of mice with EDR (400 mg/kg b.w.) significantly reduced the serum activities of ALT, AST and ALP, and the levels of hepatic MDA, but increased the activities of GSH-Px, CAT and SOD in the liver. The protective effect of EDR was further supported by attenuation of the degree of damage to liver tissue. These results indicate that due to its antioxidant properties, EDR can protect mice against $\mathrm{CCl}_{4}$-induced liver damage.

\section{ACKNOWLEDGEMENT}

This work was supported by grants from National Natural Science Foundation of China (30830006, 31070080, 31210103904), and the Fundamental Research Funds for the Central Universities from Zhejiang University (2012FZA6014), and Key Innovation Team Program of Zhejiang Province (2010R50033). The first two named authors contributed equally to this work.

\section{REFERENCES}

1. Aruoma OI. Free radicals, oxidative stress, and antioxidant in human health and disease. J Am Oil Chem Soc 1998; 75: 199-212.

2. Williams GM, latropoulos MJ, Whysner J. Safety assessment of butylated hydroxyanisole and butylated hydroxytoluene as antioxidant food additives. Food Chem Toxicol 1999; 37: 1027-1038.

3. Moure A, Franco D, Sineiro J, Domínguez $H$, Núñez MJ, Lema JM. Evaluation of extracts from Gevuina avellana hulls as antioxidants. J Agric Food Chem 2000; 48: 3890-3897.

4. Krinsky NI, Johnson EJ. Carotenoid actions and their relation to health and disease. Mol Aspects Med 2005; 26: 459-516.

5. Zhang $X$, Zhao W, Hu L, Zhao L, Huang J. Carotenoids inhibit proliferation and regulate expression of peroxisome proliferators-activated receptor gamma (PPARy) in K562 cancer cells. Arch Biochem Biophys 2011; 512: 96-106.

6. Tripathi $D N$, Jena $G B$. Intervention of astaxanthin against cyclophosphamide-induced oxidative stress and DNA damage: A study in mice. Chem-Biol Interact 2009; 180: 398-406.

7. Battista JR. Radiation resistance: the fragments that remain. Curr Biol 2000; 10: 204-205.

8. Lemee L, Peuchant E, Clerc M. Deinoxanthin: a new carotenoid isolated from Deinococcus radiodurans. Temhedron 1997; 53: 919-926.

9. Tian B, Xu Z, Sun Z, Lin J, Hua Y. Evaluation of the antioxidant effects of carotenoids from Deinococcus 
radiodurans through targeted mutagenesis, chemiluminescence, and DNA damage analyses. Biochem Biophys Acta 2007; 1770: 902-911.

10. Tian B, Sun Z, Shen S, Wang $H$, Jiao J, Wang L, Hu Y, Hua $Y$. Effects of carotenoids from Deinococcus radiodurans on protein oxidation. Lett Appl Microbiol 2009; 49: 689-694.

11. Singh N, Kamath V, Narasimhamurthy K, Rajini PS. Protective effect of potato peel extract against carbon tetrachloride-induced liver injury in rats. Environ Toxicol Phar 2008; 26: 241-246.

12. Oyaizu M. Studies on product of browning reaction prepared from glucose amine. Japn J Nutr 1986; 44: 307-315.

13. Dinis TCP, Maseira VMC, Almeida LM. Action of phenolic derivatives (acetaminophen, salicylate, and 5aminosalicylate) as inhibitors of membrane lipid peroxidation and as peroxyl radical scavengers. Arch Biochem Biophys 1994; 315: 161-169.

14. Ohkawa H, Ohishi N, Yagi K. Assay for lipid peroxides in animal tissues by thiobarbituric acid reaction. Anal Biochem 1979; 95: 351-358.

15. Cheng N, Ren N, Gao H, Lei X, Zheng J, Cao W. Antioxidant and hepatoprotective effects of Schisandra chinensis pollen extract on $\mathrm{CCl}_{4}$-induced acute liver damage in mice. Food Chem Toxicol 2013; 55: 234-240.

16. Huang QF, Zhang SJ, Zheng L, He M, Huang RB, Lin X, Hepatoprotective effects of total saponins isolated from Taraphochlamys affinis against carbon tetrachloride induced liver injury in rats. Food Chem Toxicol 2012; 50: 713-718.

17. Vertuani S, Angusti A, Manfredini S. The Antioxidants and Pro-Antioxidants Network: An Overview. Curr Pharm Design 2004; 10: 1677-1694.

18. Amarowicz R, Pege RB, Rahimi-Moghaddam P, Barl B, Weil JA. Free-radical scavenging capacity and antioxidant activity of selected plant species from the Canaian prairies. Food Chem 2004; 84: 551-562.

19. Fan $L, L i J$, Deng K, Ai L. Effects of drying methods on the antioxidant activities of polysaccharides extracted from Ganoderma lucidum. Carbohydr polym 2012; 87: 1849-1854.

20. Girotti AW. Lipid hydroperoxide generation, turnover, and effector action in biological systems. J Lipid Res 1998; 39: 1529-1542.

21. Muriel P. Nitric oxide protection of rat liver from lipid peroxidation, collagen accumulation, and liver damage induced by carbon tetrachloride. Biochem Pharmacol 1998; 56: 773-779.

22. Somasundaram A, Karthikeyan $R$, Velmurugan $V$, Dhandapani B, Raja M. Evaluation of hepatoprotective activity of Kyllinga nemoralis (Hutch \& Dalz) rhizomes. J Ethnopharmacol 2010; 127: 555557.

23. Gan $D$, Ma L, Jiang $C$, Wang $M$, Zeng X. Medium optimization and potential hepatoprotective effect of mycelial polysaccharides from Pholiota dinghuensis $\mathrm{Bi}$ against carbon tetrachloride-induced acute liver injury in mice. Food Chem Toxicol 2012; 50: 26812688.

24. Orhan IE, Sener B, Musharraf SG. Antioxidant and hepatoprotective activity appraisal of four selected Fumaria species and their total phenol and flavonoid quantities. Exp Toxicol Pathol 2012; 64, 205-209.

25. Shen X, Tang Y, Yang R, Yu L, Fang T, Duan J. The protective effect of Zizyphus jujube fruit on carbon tetrachloride-induced hepatic injury in mice by antioxidative activities. J Ethnopharmacol 2009; 122, 555-560.

26. Zhang Z, Lv G, Pan H, Pandy A, He W, Fan $L$. Antioxidant and hepatoprotective potential of endopolysacccharides from Hericium erinaceus grown on tofu whey. Int J Biol Macromol 2012; 51: 1140-1146.

27. Kew MC. Serum aminotransferase concentration as evidence of hepatocellular damage. Lancet 2000; 355: 591-592.

28. Vuda M, D'Souza R, Upadhya $S$, Kumar V, Rao $N$, Kumar V, Boillat $C$, Mungli P. Hepatoprotective and antioxidant activity of aqueous extract of Hybanthus enneaspermus against CCl4-induced liver injury in rats. Exp Toxicol Pathol 2012; 64: 855-859.

29. Halliwell B, Gutteridge JMC. Free Radicals in Biology and Medicine, 2nd ed. Oxford University Press, Oxford 1989; pp 86-105.

30. Reiter RJ, Tan D, Osuna C, Gitto E. Actions of melatonin in the reduction of oxidative stress. J Biomed Sci 2000; 7: 444-458.

31. Yao D, Shi W, Gou Y, Zhou X, Yee AT, Zhou Y, Liu Z. Fatty acid-mediated intracellular iron translocation: $A$ synergistic mechanism of oxidative injury. Free Radical Bio Med 2005; 39: 1385-1398.

32. Naik SR. Antioxidants and their role in biological functions: an overview. Indian Drugs 2003; 40: 501 516. 